\title{
Effects of Curcumin on Lipid Peroxidation and Antioxidant Enzymes in Kidney, Liver, Brain and Testis of Mice Bearing Ehrlich Solid Tumor ${ }^{+}$
}

\author{
Mustafa Nisari ${ }^{1, *}$, Seher Yılmaz ${ }^{2}$, Tolga Ertekin ${ }^{3}$, Dilek Ceylan ${ }^{4}$, Neriman İnanç ${ }^{1}$, Özge $\mathrm{Al}^{5}$ \\ and Harun Ülger ${ }^{5}$ \\ 1 Department of Nutrition and Dietetics, Faculty of Health Sciences, University of Nuh Naci Yazgan, \\ Kayseri 38090, Turkey \\ 2 School of Medicine, Department of Anatomy, Bozok University, Yozgat 66100, Turkey \\ 3 School of Medicine, Department of Anatomy, Kocatepe University, Afyon 03200, Turkey \\ 4 Genome and Stem Cell Center, University of Erciyes, Kayseri 38039, Turkey \\ 5 School of Medicine, Department of Anatomy, Erciyes University, Kayseri 38039, Turkey \\ * Correspondence: mnisari@nny.edu.tr \\ + Presented at the 2nd International Conference on Natural Products for Cancer Prevention and Therapy, \\ Kayseri, Turkey, 8-11 November 2017.
}

Published: 10 November 2017

\begin{abstract}
Cancer is the second most common cause of death in the world. Several natural products have been studied for anticancer activity and for prevention or repair of oxidative injury. Curcumin is one of the natural products of high medicinal interest. This study was performed to investigate effects of curcumin on lipid peroxidation and antioxidant enzymes in tissues of mice bearing Ehrlich solid tumor. Forty mice were distributed to four groups as healthy control and treatments that received $1 \times 10^{6}$ Ehrlich ascites tumor (EAT) cells and EAT cells plus $25 \mathrm{mg} / \mathrm{kg} /$ day or $50 \mathrm{mg} / \mathrm{kg} /$ day curcumin subcutaneously. The liver, kidney, brain and testis tissues were collected for the malondialdehyde, superoxide dismutase and catalase analyses. Tumor development increased MDA levels in liver $(p=0.001)$, kidney $(p<0.001)$ and testis $(p<0.01)$ and curcumin reduced liver Mathew decreased liver and kidney SOD activities were increased by both levels of curcumin $(p=$ $0.001)$ but $50 \mathrm{mg} / \mathrm{kg} /$ day curcumin increased brain SOD activity $(p<0.001)$. The kidney CAT activity was increased by $50 \mathrm{mg} / \mathrm{kg} /$ day curcumin $(p<0.001)$. This study showed that curcumin suppresses tumor progression, and alleviates the lipid peroxidation and improves antioxidant status in the tissues of solid tumor-bearing mice.
\end{abstract}

Keywords: Curcumin; Ehrlich solid tumor; lipid peroxidation; antioxidant enzymes

(C) 2017 by the authors. Licensee MDPI, Basel, Switzerland. This article is an open access article distributed under the terms and conditions of the Creative Commons Attribution (CC BY) license (http://creativecommons.org/licenses/by/4.0/). 